DOI 10.14746/ssp.2019.2.5

\title{
Vadym ZheLTOVSKYY
}

Pultusk Academy of Humanities

ORCID: 0000-0002-4403-0557

\section{Civil society as an actor in the political processes of local governance reform in Ukraine}

\begin{abstract}
One of the first laws adopted by the new political leadership in Ukraine in the aftermath of the Revolution of Dignity in 2014 was the new concept of local governance reform and the organization of territorial authority in Ukraine. The aforementioned law, as well as official declarations by top politicians on the necessity of empowering Ukrainian citizens to take part in the decision-making process and shape their local communities, led to positive expectations regarding the transformation of local governance in Ukraine. Therefore, this article addresses the issue of the legal basis framing the functioning of civil society in Ukraine, focusing on major attempts to conduct reform and on the main outcomes of implemented actions. Additionally, emphasis is placed on the current state of cooperation between social and political actors, and the trends in civil participation in the decision-making process regarding decentralization and local governance reform in Ukraine.
\end{abstract}

Key words: civil society, Ukraine, local governance reform

\section{Introduction}

7 his article analyzes civil participation in Ukraine in the context of local governance reform. The rationale for choosing civil engagement in local government reform lies in the fact that successful decentralization and local governance leads to the creation of favorable grounds for citizens to have an impact on the decision-making process on a local scale, which in turn is a crucial element of a democratic state. Therefore, the purpose of this article is to analyze the impact of the Post-Euromaidan decentralization process on the development of civil society in Ukraine. To achieve this purpose, the following research tasks have been undertaken: - analysis of the major attempts to reform the system of local government in Ukraine and research the impact of the transformation of the legal framework on civil participation in Ukraine after 2014; 
- discussion of how the citizen-official relationship has changed since the dramatic events of the Revolution of Dignity and how military conflict in Donbas has shaped the priorities and directions of civil and political actors' activities.

Taking into account the stated purpose and research aims, the main hypothesis has been formulated as the following: the active engagement of Ukrainian civil society actors in the process of local governance reform may lead to a successful transformation that would meet the expectations of the citizens in a particular community. Simultaneously, such factors as the stability of the political system and the mechanisms of international support for decentralization influence the level of civil engagement in the reforms.

The methodology of this research is based on a descriptive and analytical examination of research objectives. The method of theoretical analysis of academic literature was used in order to analyze existing scientific perspectives on the fundamental features of civil society in Ukraine in 1991-2018, and, in order to define the terms 'citizen,' 'civil society,' 'civic participation,' and 'political participation.' Furthermore, the comparison method, based on the presentation of similarities and differences between processes and phenomena, proved to be useful in the analysis of existing legal instruments compared to those which existed during the Yanukovych administration, in order to show the changes implemented by post-Euromaidan authorities. The research also utilizes other methods that are used in political science, such as institutional and legal analysis. These methods were used with a view to presenting the essence of legal documents and their influence on citizen empowerment during different periods of Ukrainian independence, with particular attention paid to the post-Euromaidan period.

\section{Definition of key terms}

Prior to the analysis of civic participation in Ukraine, this article presents the existing research on the given issue and definitions of terms such as 'civil society,' 'civic participation,' 'political participation,' 'citizen' and 'active citizenship,' which are of considerable importance for the undertaken research.

A number of scholars have made valuable attempts to define the key constituents of civil society and civic engagement in different countries. 
In their broad study on transitions from authoritarian systems to democracy, Karatnycky and Ackerman assert that successful transitions require the creation of a dynamic civil society. Among the most essential constituents of a dynamic civil society, authors emphasize the following: general assistance for civil society actors, with a particular focus on education and training in civic nonviolent resistance, and assistance for the establishment of civic coalitions that would serve as a basis for such resistance (Karatnycky, Ackerman, 2005, p. 11).

Regarding definitions of the term 'civil society,' Way uses it to broadly refer to the voluntary networks of independent organizations and institutions that are not controlled by the state. Like Way, one might assess the strength of civil society according to three criteria: civil society as a 'traffic cop' that acts as a facilitator of existing protest activity; civil society as a 'dispatcher' that mobilizes people to start protests; and in the framework of the institutionalization or stability of protest organizers (Way, 2005, p. 37).

Meanwhile, Kolodiy considers the constituents of civil society to be institutions that should serve a number of functions: (1) as a tool for the self-expression of individuals, their self-organization and realization of their own interests; (2) as a guarantee for citizens' individual rights and as a helping instrument in cases of citizens' struggle with a state; (3) as an advocate for a particular social group at the level of state official; (4) as a basis for the democratic state order, etc. (Kolodiy, 2002).

Additionally, Barret and Zani define the term 'citizen' as any individual who can participate in political and civic processes, or be affected by political and civic decision-making (Barrett, Zani, 2015, p. 3). In this context, interesting insights have been provided by Peter Levine and Karol Soltan, who define the elements that are necessary for being a good citizen. These scholars argue that good citizens are open to different opinions and to reaching a consensus. At the same time, in order to make changes, deliberation should go hand in hand with work and collaboration. In this case, "people make things of public value together" (Levine, 2013, p. 3). Karol Sołtan defines citizens as co-creators of their worlds. In his definition of the emerging field of civic studies, Soltan argues that it is not a citizen but "a society full of civic initiatives" that is the relevant image and inspiration for civic studies or the "new civics." In fact, the term 'civic studies' was coined in 2007 by seven respected scholars with the following definition of its aim: "to understand and strengthen civic politics, civic initiatives, civic capacity, civic society and civic culture" (Sołtan, 2014, p. 9). 
As far as scientific perspectives on civic and political participation are concerned, Zukin et al. point out the distinction between two notions. As a matter of fact, most authors accept the definition of political engagement proposed by Verba, Schlozman, and Brady, who defined political engagement as "activity that has the intent or effect of influencing government action - either directly, by affecting the making or implementation of public policy, or indirectly, by influencing the selection of the people who make those policies." At the same time, civic engagement is defined as an organized individual or group voluntary activity focused on problem-solving and helping others (Zukin et al., 2006, pp. 6-7). Both definitions presented above were used by Barrett and Brunton-Smith in their article Political and Civic Engagement and Participation: Towards an Integrative Perspective. These authors analyze multiple levels of factors (macro-contextual, demographic, psychological, etc.) that influence both civic and political participation (Barrett, Brunton-Smith, 2014).

Furthermore, Barrett and Zani discuss factors and processes that influence civic and political participation in Europe and refer to ideas presented by Zukin et al. and Barrett and Brunton-Smith, pointing out the variety of different forms of civic and political engagement. Additionally, these authors connect political engagement with political institutions, processes and decision-making, while civic participation is connected with interests, goals, concerns and the common good of a particular community. Scholars emphasize that both types of engagement involve active participatory behaviors (Barret, Zani, 2015, p. 4).

Levine and Lee attempt to find a new model for the engagement of citizens in the United States, and advise municipal governments to enlist "more citizens in more consequential civic work" (Levine, Lee, 2016). These authors emphasize the capacity of municipal governments to turn ordinary volunteering into opportunities for deliberation about issues, collective action, and establishing relationships among representatives of municipalities and local communities (Levine, Lee, 2016).

In their reflections on the essence of the term 'civic engagement,' Adler and Goggin assert that even though this term has mainly been used in literature on the subject in reference to younger people, a new movement has appeared promoting greater civic engagement among older adults. Additionally, scholars quote Robert Hollister, who preferred the term 'active citizenship' as an alternative to civic engagement with emphasis on collective action (Adler, Goggin, 2005, p. 238). 
Concerning the issue of collective action, Sirianni reflects on collaborative governance, stressing the importance of a pragmatic approach to the questions of policy design, complex governance and democratic theory. As an example of successful collaborative governance, the author emphasizes the significance of encouraging ordinary citizens to actively co-produce public goods. Taking into account the complexity of public goods, they often cannot be effectively produced and delivered by a direct tool of government. Therefore, policy should engage ordinary citizens, in cooperation with public servants and other professionals, in producing certain public goods. One important aspect of this is that the role of citizens should not be narrowed to simply advocating for public goods, paying for them through taxes, and then consuming them as services and benefits. Instead, it should help provide the tools and templates to enable citizens to become skilled, responsible and effective producers of these goods (Sirianni, 2009, p. 42).

On the subject of civic engagement in Europe, Alla Marchenko has conducted comparative research based on European Values Studies. According to Marchenko, "civic engagement is a multi-faceted phenomenon which could be analyzed from three regimes of engagement, offered by Laurent Thevenot: the regime of familiar engagement, the regime of engagement in a plan, and the justifiable action engagement regime." When speaking about post-soviet European states, this scholar underlines their correspondence to the regime of familiar engagement, which means personal attitudes dominate over activities (Marchenko, 2014, p. 350).

\section{Civil society in Ukraine - literature review}

Academic literature has approached civil society in Ukraine from a number of perspectives. In 2001, Taras Kuzio published his article on the issue of identity and nation-building in Ukraine, asserting that the disintegration of the Soviet Union had created grounds for the revival, evolution and strengthening of identity among Ukrainians. He predicted the establishment of a national identity of Ukraine based on "emphasizing itself as part of central-eastern Europe" and thus "contrasting itself to the Russian, former Soviet and Eurasian 'other'." At the same time, Kuzio pointed to the lack of consensus between competing political groups in Ukraine, who either associated themselves with Europe or with Russia (Kuzio, 2001, p. 344). 
The European identity of some Ukrainians could be observed during the Orange Revolution in 2004. As Kaskiv, Chupryna and Zolotariov summarize in their article on the PORA movement, prior to the 2004 Orange Revolution there were growing authoritarian tendencies in Ukraine, which led to the restriction of citizens' fundamental freedoms and rights. These authors defined the key features of the Ukrainian situation that influenced the implementation of PORA's civic educational initiative. Among the most important are the following: large territory and population; historical, social and cultural heterogeneity; different levels of access to the independent mass media in different regions; and Russian interference in Ukrainian elections (Kaskiv, Chupryna, Zolotariov, 2005, p. 129). In the context of media access, Nadia Diuk emphasized the considerable number of people following the Orange Revolution "by watching Channel 5, listening to Radio Era or hearing from friends and relatives in Maidan" (Diuk, 2006, p. 70); and Forbrig and Demes point to the primary goal of the PORA initiative, which was to provide voters with sufficient information to make a choice. In this way, civic activists were contributing to a "meaningful political change" (Forbrig, Demes, 2005, p. 179).

Regarding research on the nature and strength of Ukraine's civil society, scholars have concentrated their research on three Ukrainian revolutions (the Revolution on the Granite in 1990, the Orange Revolution in 2004 and the Revolution of Dignity in 2013) that are considered to be examples of the mobilization of Ukrainian civil society, which challenges claims regarding its weakness (Burluyk, Shapovalova, Zarembo, 2017, p. 2). Lucan Way adds one more protest to this list of social mobilizations in Ukraine that resulted in the ousting of chief executives - the 1993 strikes by miners from eastern Ukraine that led to early presidential elections (Way, 2014, p. 35).

On the other hand, the inability of Ukrainian civil society to implement changes in the aftermath of these revolutions is regarded as a sign of weakness. Orysia Lutsevych defines "a lack of engagement, clientelistic networks and corruption" as factors leading to the weak position of civil society in Ukraine in 2013 (Lutsevych, 2013, p. 1). Way asserts that Ukraine's civil society is relatively weak, stresses the inability of groups to mobilize large number of citizens without the support of private networks, and highlights the need to find ways to mobilize society which would not lead to greater violence and threaten the existing fragile polity (Way, 2014, p. 42). 
Meantime, in their latest research paper, Lutsevych et al. underline the impact of the mobilization of civil society in the aftermath of Euromaidan, and the subsequent reforms leading to the weakening of Russian influence in Ukraine (Boulegue, Lutsevych, Marin, 2018). Furthermore, Nadia Diuk stresses the significant role of civic groups in the post-Euromaidan legislation work on a "reanimation package" of reforms (Diuk, 2014, p. 89).

Similar ideas are expressed by Worschech, who argues that the Revolution of Dignity led to the unprecedented growth of civil society in Ukraine and made it possible for Euromaidan activists and journalists to enter the political sphere. He continues saying that the unique feature of changing civil society in the post-Euromaidan period has been its ability to establish and further develop trust networks in Ukraine, to an extent that has not been seen before. At the same time, he points to the potential threats to civil society in Ukraine such as decreasing enthusiasm for civic engagement, the potential complications connected with "the transfer of crisis-centered volunteer networks into long-term policy-oriented civil society," or the legitimacy of new players, which often stems from their reputation rather than democratic procedures (Worschech, 2017, p. 24).

Speaking about the evolution of civil society in Ukraine in 2018, Natalia Shapovalova points out the positive dynamics of strengthening civil society since 2014, and, importantly for this article, emphasizes the first fruitful outcomes of decentralization reforms implemented by the postEuromaidan authorities that created space for greater civil engagement in local initiatives, and for increased transparency and responsibility in local government. At the same time, as Shapovalova asserts, the level of support for grassroots groups, who often act locally supported by international donors, remains insufficient (Shapovalova, 2019). Interestingly, similar critical remarks on the necessity for Western donors to establish a new paradigm for the support of civil society in Ukraine were expressed by Lutsevych in 2013, who asserted that existing models of Western support did not affect much of Ukrainian society and were mainly concentrated on "supporting the patronage network NGOs and maintaining the gap between a few well-connected groups and the wider public" (Lutsevych, 2013, p. 16).

The brief literature review presented above illustrates the topicality of studies on citizens' roles in a state and civil engagement in political processes, which is the focus of this article. Thus, the following sections of the paper will concentrate on the examination of such issues as the le- 
gal basis for the effective functioning of civil society in Ukraine, and the evolution of the tradition of cooperation between civil and political actors on the matter of local governance reform.

\section{Legal basis of civil participation in Ukraine}

Regarding Ukraine, the issue of the forms of civil participation guaranteed by the state and the evolution of a legal framework for participation should be addressed. According to the Ukrainian Constitution, the Ukrainian people are the prime source of power (Art. 5, Constitution of Ukraine). Thus, the task of primary importance is to establish legal grounds for citizens' engagement in decision-making on the one hand, and finding ways to encourage cooperation between officials and citizens on the other.

Regarding public participation in the local governance process, Harnec et al. emphasize that one should not only speak about decentralization in the context of state power decentralization, which assumes the transition of more responsibilities to local governments, but also about the decentralization of local governance. Analysts see the realization of this kind of decentralization of local governance in the establishment of civil society institutions and/or business structures. To achieve this, the state should implement legal mechanisms of civil participation enabling citizens to take part in the decision-making process at the local level (Harnec, 2013, p. 81).

This article therefore makes an attempt to analyze the key legal acts and initiatives on local governance reform and citizen empowerment adopted or initiated since 2014 by key political actors in Kyiv. Emphasis is placed on presidential initiatives and the comparative analysis of national strategies on the development of local governance adopted in 2012 and 2016.

Regarding major attempts to reorganize the system of power in Ukraine during its 27 years of independence, it was the centralized model of power that led to internal controversy between central and local authorities because of an unclear division of state functions and powers between them, the replication of many functions, complicated budgetary relations, etc. (Izha, Krupnyk, 2012, p. 3). Moreover, it became an impediment to the development in the various regions, which led to a range of discussions on the decentralization process with the participation of many ac- 
tors. These attempts led to no significant changes, and often declarations with sound advice and expertise did not lead to any practical outcomes. The reason for this might be found in the unwillingness of state administrators to change the rules of the game. As a result, the question of transparency and professionalism in public service remained topical throughout the years of reform.

Therefore, it came as no surprise that one of the first laws adopted after the Revolution of Dignity was the concept of local governance reform and the reorganization of territorial authority in Ukraine, which was approved by the Cabinet of Ministers of Ukraine on April 1, 2014. This law was of particular importance and may be regarded as a message from the post-Maidan leadership to the domestic and international audience. Having been adopted almost two months before the presidential elections and half a year before the early parliamentary elections, this law illustrated the willingness of the new authorities to establish legal norms for active civil participation in the Ukrainian regions. Moreover, the topic of local governance reform and decentralization was high on the political agendas of all parties participating in the 2014 parliamentary election in Ukraine (Political parties', 2014).

Furthermore, the issue of citizen empowerment in presidential agenda should be emphasized. Regarding the presidential impact on the legal framework of local governance in Ukraine, every Ukrainian president put significant effort into changing the Ukrainian Constitution, with the view to gaining more favorable conditions for the realization of his agenda. One of the most vivid examples of this was the adoption of the 1996 Ukrainian Constitution establishing a presidential-parliamentary form of government, and as Frye puts it, making the Ukrainian president one of the strongest in terms of power over the country's legislature, similar to those in Russia or Belarus (Frye, 1997, p. 547). Significantly, one of the popular arguments in favor of the need to make these changes to the Constitution was the statement that such changes would lead to the effective reform of local governance across Ukraine (Christensen et al., 2005, p. 207).

In order to answer the question of changes regarding the issue of local governance after 2014, one should study the way in which President Poroshenko has approached the matter of local governance in his legal initiatives. The first issue that should be taken into consideration is the concept of constitutional changes. Unlike local governance, this was not presented to the public immediately after the presidential election. The first step was made on March 3, 2015, when Poroshenko signed his order 
\#119/2015 on the Constitutional Commission. According to this presidential order, the main aim was to reach political and social consensus on the improvement of the constitutional regulation of social relations in Ukraine (Presidential Order \#119/2015). As a result of workgroup discussions, a wide range of issues were analyzed. Interestingly, proposals from the decentralization workgroup were the last to be presented. However, the presenter of final decentralization proposals was the President himself. The timing of the speech was also symbolic. The key message that "decentralization will bring the Ukrainian political system closer to the European system" "was delivered by President Poroshenko in Verkhovna Rada on July 16,2015 , on the $25^{\text {th }}$ anniversary of the Declaration of State Sovereignty of Ukraine. ${ }^{2}$

Furthermore, the Bill number 2217 On Amendments to the Constitution of Ukraine (concerning the decentralization of power), adopted by the Constitutional Commission, was sent to the Constitutional Court of Ukraine for review. It should be mentioned that this document was a topic of discussion on many domestic and foreign forums, including the discussion between Ukrainian top officials and leaders of the Normandy format $^{3}$ or the European Venice Commission, whose Head described it as probably the only real approach that was possible in the current situation (The Insider). In turn, the German and French leaders noted that the introduction of decentralization amendments and further constitutional reform would guarantee the consolidation of democracy in Ukraine and the implementation of the Minsk agreements. Furthermore, the U.S. Assistant Secretary of State, Victoria Nuland, visited Kyiv before the vote on this bill in Verkhovna Rada and was present alongside the U.S. Ambassador to Ukraine in the parliament during the voting.

Concerning the essence of the 9-page decentralization proposal, the following aspects should be stressed:

${ }^{1}$ For full text of presidential speech see: http://www.president.gov.ua/news/vistup-prezidenta-ukrayini-na-plenarnomu-zasidanni-verhovnoy-35657.

2 The Declaration establishing the principles of Self-Determination of the Ukrainian Nation, Rule of the People, State Power, Citizenship, Territorial Supremacy, Economic Independence, Environmental Safety, Cultural Development, External and Internal Security, and International Relations.

3 The Normandy format is a diplomatic group of senior representatives of four countries (Germany, Russia, Ukraine and France) which met to resolve the crisis situation in the East of Ukraine. The Normandy format operates mainly through telephone calls between the Ukrainian, Russian and French presidents, the German chancellor and their respective ministers of foreign affairs. 
- as before, Ukraine is made up of 27 regions, including the Crimean peninsula and city of Sevastopol;

- the administrative territorial system of Ukraine includes hromady, districts (rayons) and regions;

- the amount of districts (rayons) is reduced from 490 to 150;

- district (rayon) includes several territorial communities (hromady) that unite several villages or towns;

- hromady are the primary, basic, and main unit of the administrative and territorial system of Ukraine. They receive the right to decide on primary and secondary education, emergency services, municipal police, social protection, landscape of territories, etc.;

- hromady elect councils that constitute the executive body, with an elected head of the council;

- the regional council appoints an executive body that replaces regional state administrations;

- the office of the Prefect as a controlling body is appointed by the President after nomination by the Cabinet of Ministers. The main task of the Prefect will be to oversee compliance with the Constitution in the policies of local councils, etc. (Draft Law...). According to Poroshenko speaking in Parliament, "Prefects would have nothing to do with the management of budget flows and financial resources of the local government. They would not govern, but only perform monitoring functions" (President: Decentralized).

In terms of the reaction to the voting on the decentralization proposal, most comments refer to the proposed amendment regarding occupied parts of the Donetsk and Lugansk regions, stating that the "peculiarities of local governance in certain districts of the Donetsk and Lugansk regions are defined by separate law" (Draft Law...).

In order to further follow the changes in political declarations regarding providing support for civil society in Ukraine, the National Strategies on the Development of Civil Society in Ukraine adopted in 2012 and 2016 should be analyzed. Interestingly, comparing the problems faced by civil society before the Revolution of Dignity, which were reflected in the 2012 Strategy and signed by Victor Yanukovych, with the problems presented in 2016-2020 Strategy signed by Petro Poroshenko, one can find a range of similar challenges, such as:

- low level of transparency in the activities of local authorities;

- high levels of bureaucracy in the relationship between authorities and civil activists; 
- flaws in the legal system creating artificial barriers to the implementation of civil initiatives;

- lack of effective civil control over local authorities' performance;

- insufficient engagement of civil activists in the formation of state policy;

- lack of incentives for civil society institutions, etc.

At the same time, the most significant difference between the documents lies in the evaluation of civil society and their attempts to be part of state development process. The 2012 Strategy includes critical remarks towards the low level of awareness of democratic mechanisms among citizens and their inability to self-organize in order to solve social problems. Moreover, among other obstacles to the development of civil society were listed low levels of public awareness of basic concepts such as 'civil society,' 'democracy,' 'rule of law,' the principle of the separation of powers, coordination of interests, tolerance and consensus, and respect for human minorities.

The 2016 Strategy includes no such criticism. Conversely, all blame is put on the authorities and their inability to provide civil society with the necessary conditions for successful development and fruitful cooperation. This criticism includes the lack of a unified state policy on the promotion of civil society values, insufficient access of civil organizations to state financial support, unclear selection processes during grant applications, etc. ${ }^{4}$

Regarding the goals and principles of the 2016-2020 Strategy, this document states that its main purpose was to create favorable conditions for the development of civil society, establish effective cooperation between the public and governmental authorities on the basis of partnership, provide additional opportunities for the realization and protection of the rights and freedoms of citizens, and meet social interests with the help of various forms of participatory democracy, public initiatives and selforganization.

Additionally, four strategic goals are declared:

1) the creation of favorable conditions for the development and institutional development of civil society;

2) ensuring effective procedures for public participation in the shaping and implementation of state and regional policy issues of local importance;

${ }^{4}$ Based on the author's comparative analysis of the Strategies on the Development of Civil Society adopted in 2012 and 2016. 
3) stimulating the participation of civil society in the socio-economic development of Ukraine;

4) the creation of favorable conditions for inter-sectoral collaboration (2016-2020 Strategy).

The most important aspect is the participation of NGO representatives and OSCE experts, who conducted research on civil society dynamics and activities in Ukraine during the development and official signing of the document. As a matter of fact, the OSCE Project Coordinator in Ukraine has been organizing regional discussions on revising the existing strategy in light of the new trends, opportunities and challenges for Ukrainian civil society.

Any analysis of the legal framework for the development of Ukrainian local governance would not be complete without taking into account the latest changes that were adopted by Ukrainian parliament in 2017. These changes include the voluntary amalgamation and status of the starosta (head) of villages and settlements. In fact, the amalgamation of hromady into larger territorial communities enables more effective management and creates conditions for the more successful implementation of local initiatives. As a matter of fact, by February 10, 831 amalgamated territorial units had been created. Thus, as of February 2019, almost $20 \%$ of the Ukrainian population lived in amalgamated territorial units.

Experts point out the positive aspects of the amalgamation process, such as the legal authority vested in local communities, the engagement of human capital in local processes, and inter-communal cooperation. On the other hand, the slow process of taking control over basic public services due to the voluntary nature of hromady unification is defined as a problematic aspect of the process (Rabinovych, Brown, Umland, 2018). On the whole, observers agree that the major impediment to the process of decentralization and local governance reform is the lack of constitutional amendments for this purpose (Nations in Transit 2018; Rabinovych, Brown, Umland, 2018).

\section{Cooperation between social and political actors}

Having presented the legal initiatives on local governance reform and the issue of civil access to the decision-making process in the political program of Ukrainian government, focus of the latter part of this article will be on the state of cooperation between social and political actors in the Ukrainian regions. 
The above-mentioned concept of local government reform in Ukraine illustrates the intention of the central authorities in Kyiv to implement the model of gradual, transparent and open mechanisms of local democracy. However, as many scholars assert, international experience vividly shows that the successful implementation of reforms comes as the result of a complicated search for compromise and public dialogue between the government, business, institutions of civil society and citizens (Kovbasiuk, 2014, p. 92).

Regarding the evolution of civil society organizations, a number of positive changes happened after 2014. If in 2012 Ukrainian researchers described Ukrainian society as transitive and non-consolidated (Vinnikov, 2012), by 2015 Gorbulin et al. pointed to a rapid structure-building process in the civil sector and the role of self-organized groups of activists in volunteer or charity movements aimed at solving the crucial problems of the Ukrainian state which, according to the authors, proved the maturity of Ukrainian civil society and its readiness to influence the transformation of the socio-political reality. Since the Revolution of Dignity, the major focus of volunteers' activity was support for democratic aspect of national development, support for the security of Ukraine and aid to people suffering due to the military tensions in the Donbas region (Gorbulin et al., 2015, p. 185).

Civil participation in internal political transformations is said to be a beneficial factor for the transparency mechanisms being built in the sphere of national security. Furthermore, the Civil Lustration Committee of Ukraine took an active role in the development of legal acts On Restoring Confidence in the Judicial System of Ukraine and On Power Purge. The aforementioned laws are important steps toward the democratization of Ukrainian society, as they put limits on admission to involvement in the administration of state affairs by individuals who worked in close cooperation with Viktor Yanukovych and whose decisions or lack of decisions led to threats to the national security of Ukraine or the violation of human rights and freedom.

Another document including advice from civil society activists is the Ukraine 2020 Strategy which defines goals and indicators to measure their achievement, as well as directions and priorities for state development. As the authors put it, the purpose of the reforms is to achieve the European standard of living and the rightful place for Ukraine in the world. Among the priority objectives were decentralization and local governance reform (Ukraine 2020 Development Strategy).

Overall, scholars speak with one voice on the necessity of regular cooperation between state institutions and the structures of civil society, with the view to monitoring and influencing the decision-making pro- 
cess. In order to reach qualitative changes in government and successfully implement state policy, reform of the state management system (presidential, parliamentary, government, prosecutor, constitutional) and the implementation of public control should be synchronized. At the same time, active public participation in the formation and implementation of state and local policies became possible as a result of the enhancement of the civil network which operates alongside executive authority bodies (Gorbulin et al., 2015, p. 89).

Speaking about cooperation between social and political actors in PostEuromaidan Ukraine, it is important to stress the state of international cooperation between Ukrainian and Polish NGOs on the matter of local government reform and their impact on the development of these reforms in Ukraine.

As far as non-governmental organizations are concerned, in 2003 Piotr Kosiewski divided the cooperation between Polish and Ukrainian NGOs after 1989 into three stages:

1. 1989-1994 - initial period of creating contacts between partners. Mainly this included organizations engaged in parallel activities such as the Education for Democracy Foundation (pol.: Fundacja Edukacja dla Demokracji), Helsinki Foundation for Human Rights, KARTA Center Foundation (pol. Fundacja Ośrodka KARTA), Polish-CzechSlovak Solidarity Foundation (pol: Fundacja Solidarności PolskoCzesko-Stowackiej), and the Institute for Democracy in Eastern Europe (IDEE). The period is characterized by the launch of the first international projects. Additionally, donations were provided by U.S. foundations: National Endowment for Democracy, Ford Foundation and Charles Stewart Mott Foundation.

2. 1995-1998 - this period is characterized by the engagement of Polish NGOs actively carrying out the Polish aspects of international projects. One such example is Foundation in Support of Local Democracy (FSLD) (pol.: Fundacja Rozwoju Demokracji Lokalnej), whose representatives were engaged in local government reform in Ukraine.

3. Since 1999 - significant increase of NGOs cooperating with Ukrainian partner organizations. Practically every respected NGO in Poland has been engaged in different forms of cooperation with Ukrainian counterparts, and a number of local organizations from the Eastern and Southern regions of Poland have expressed their will to cooperate with the Ukrainian side (Kosiewski, 2003, pp. 8-9).

Regarding cooperation trends since 2003, a group of researchers have attempted to analyze the engagement of Polish local government units in 
implementing of the Eastern Partnership (EaP) Programme. Skorupska asserts that about $70 \%$ of local governments in Poland have had foreign partners in recent years, which was influenced by a number of factors such as the size of these units and their geographical location. The importance of geographical position may be enhanced by the fact that at the gmina (municipality) level international cooperation is usually not among the top priorities of the local authorities, with the exception of local governments situated in the border regions, where contact with the neighboring country has become commonplace (Skorupska, 2015).

Tarczyńska presents the results of the 2013 Ministry of Administration and Digitalization of Poland's poll of representatives of local and regional government participating in the Eastern Partnership initiative. Regarding the issue of international cooperation, the scale of cooperation with Eastern partnership states was in second position following cooperation with EU member states. Interestingly, at the level of region, 100\% of respondents declared that they were involved in cooperation with partners from the EaP, while cooperation with EU member states took second place with $93 \%$. At the level of powiats (districts), the balance was practically even, but slightly in favor of the EaP: 56 respondents confirmed cooperation with EU member states, and 58 with states from EaP. At gmina level, cooperation within the European Union was clearly more intensive: 215 respondents, compared to 174 respondents cooperating with partners from outside the European Union (Tarczyńska, 2013, pp. 47-49).

Particular attention should be paid to the role of Polish NGOs that have been providing their Ukrainian counterparts with valuable insights into the peculiarities of local governance reform in Poland. The Foundation in Support of Local Democracy might serve as an example of Polish non-governmental engagement in local governance reform assistance in Ukraine. Currently, the project concentrates on support for the model of strategic participatory planning in the municipalities of Western and Central-Northern Ukraine. The purpose of the project is increasing the potential of local authorities and local NGOs in terms of the establishment of participatory mechanisms in the municipality (The Foundation...).

The Foundation in Support of Local Democracy also participates in a number of international projects on decentralization and local government reform in Ukraine financed by international donors. One example is the Decentralization Offering Better Results and Efficiency (DOBRE) program aimed at directing technical and financial assistance at the local level, with particular focus on newly formed amalgamated territorial units. Addi- 
tionally, the main emphasis is placed on the issue of increasing the quality of public services, local economic growth, and creating grounds for better civil engagement (Decentralization Offering...).

These examples illustrate the significant scale of international engagement in the decentralization processes in Ukraine and the continuous attempts to motivate civil society to participate in local initiatives.

Regarding international expertise on the topic of civil society in Ukraine, the Report on CSO Sustainability Index for Central and Eastern Europe and Eurasia, 2018 Freedom House Report on Nations in Transit, and 2018 CIVICUS State of Civil Society Report have been taken into consideration in order to track and analyze the main changes regarding the overall development of civil society.

The latest study is focused on the 2016 CSO Sustainability Index for Central and Eastern Europe and Eurasia. This index analyzes and assigns scores to seven interrelated dimensions: legal environment, organizational capacity, financial viability, advocacy, service provision, infrastructure, and public image (2016 SCO Sustainability Index). Once again, the issue of decentralization and local governance was highlighted as the top priority of the new Ukrainian government under the leadership of current Prime Minister Volodymyr Groysman. More importantly, the authors of the report define civil society as "one of the strongest actors in Ukraine's democratic transition."

Among the positive changes in the functioning of civil society organizations (CSOs), the following are stressed: strategic planning of the leading CSOs, and the proactive position and positive dynamics of the engagement of CSOs in the decision-making process. In terms of the negative aspects, the report points to the limited funding available due to the economic crisis (2016 CSO Sustainability Index).

Meanwhile, in its latest report Nations in Transit 2018: Ukraine, Freedom House classified Ukraine as a "Transitional Government or Hybrid Regime," giving it a 4.64 score for democracy. Traditionally, seven characteristics have been taken into account: Electoral Process; Civil Society; Independent Media; National Democratic Governance; Local Democratic Governance; Judicial Framework and Independence; Corruption. The ratings are based on a scale of 1 to 7 , with 1 representing the highest level of democratic progress and 7 the lowest.

For the first time since 2014, the Civil Society rating declined from 2.50 to 2.75 due to a number of legal initiatives aimed at civil society activists, including a requirement to provide information on tax reporting. At the same time, it is of equal importance that the positive dynamic in Local 
Democratic Government ratings continued and improved from 5.00 to 4.75 (2018 Nations in Transit Report). One of the main reasons for this trend was the continuation of the decentralization and local governance reform and the adoption of the legal acts presented in the previous part of the article.

According to the 2018 CIVICUS report, Ukraine remained in the 'obstructed' category. This indicator has 5 categories: closed, repressed, obstructed, narrow and open. At the same time, the report stresses the significant role of civil society in establishing a functional democracy and protecting human rights (2018 CIVICUS report).

\section{Conclusions}

The analysis conducted above leads to a number of conclusions regarding the evolution of civil society role in political processes, focusing on the example of local governance transformation in Ukraine. The study of legal acts and development strategies deliberated by civil organizations or with their active participation, as well as analysis of cooperation traditions between officials and active citizens, has positively verified the hypothesis and has given grounds for positive expectations regarding the future of civil participation in the decision-making processes.

The conducted analysis leads to the following conclusive remarks:

- even though full decentralization of power is impossible without certain changes to the Ukrainian Constitution, the reform of local government has continued, with the increasing engagement of civil society actors. As a result, the number of amalgamated territorial units is constantly growing, which gives local communities the chance to shape their own policies and implement transformations. Moreover, civil society has started to take an active part in institutional changes and the development of a legal basis for the implementation of changes;

- analysis of the cooperation between Ukrainian and Polish NGOs, as well as existing programs of international support for the decentralization processes in Ukraine, have created ground for the engagement of Ukrainian NGOs in the process of reform implementation. However, according to a number of scholars, international donors should reconsider the support mechanisms for local grassroots groups, who are often not included in the analyzed projects;

- even though international reports on civil society in Ukraine present a number of potential threats and factors that negatively influence its 
development and opportunities for civil participation, evidence in favor of growing civic engagement in decision-making processes brings positive expectations regarding the strengthening of civil society. However, it remains to be seen whether the upcoming 2019 elections will change the state's approach to the engagement of civil activists in local and regional initiatives.

The final conclusion is that there is no conclusion. Civic participation in Ukraine is a process of a dynamic nature. As a matter of fact, the research has verified the hypothesis that civil society in Ukraine has become an active actor on the Ukrainian political scene in the post-Euromaidan period, and continues to have a significant influence on the decentralization processes mentioned above.

\section{References}

\section{Legal Acts on Local Government Reform in Ukraine (in Ukrainian)}

Draft Law on Amendments to the Constitution of Ukraine (concerning the decentralization of power), http://w1.c1.rada.gov.ua/pls/zweb2/webproc4_1?pf3511= $55812,3.10 .2018$.

Bill "On Restoring Confidence in the Judicial System of Ukraine", http://w1.c1. rada.gov.ua/pls/zweb2/webproc4_1?pf3511=50133, 2.10.2018.

Bill "On Power Purge", http://zakon4.rada.gov.ua/laws/show/1682-18, 2.10.2018.

National Strategy on Promotion of Civil Society in Ukraine in 2016-2020, http:// zakon4.rada.gov.ua/laws/show/68/2016/paran20\#n20, 3.10.2018.

National Strategy on Promotion of Civil Society in Ukraine adopted in 2012, http:// zakon4.rada.gov.ua/laws/show/212/2012, 3.10.2018.

Order of Cabinet of Ministers of Ukraine "On approval of the Concept of reforming the local self-government and territorial organization of power in Ukraine", http://zakon4.rada.gov.ua/laws/show/333-2014-\%D1\%80, 1.10.2018.

The Constitution of Ukraine, http://zakon5.rada.gov.ua/laws/show/254\%D0\%BA/96$\% \mathrm{D} 0 \% \mathrm{~B} 2 \% \mathrm{D} 1 \% 80,1.10 .2018$.

\section{Monographs and Academic Articles:}

Adler R., Goggin J. (2005), What Do We Mean By "Civic Engagement”?, "Journal of Transformative Education".

Barrett M, Brunton-Smith I. (2014), Political and Civic Engagement and Participation: Towards an Integrative Perspective, "Journal of Civil Society", 10(1).

Barret M., Zani B. (2015), Political and Civic Engagement: Multidisciplinary perspectives, Routledge. 
Boulègue M., Lutsevych O., Marin A. (2018), Civil Society Under Russia's Threat: Building Resilience in Ukraine, Belarus and Moldova, https://www.chathamhouse.org/sites/default/files/publications/research/2018-11-08-civil-society-russia-threat-ukraine-belarus-moldova-boulegue-lutsevych-marin.pdf, 1.10.2018.

Burlyuk O., Shapovalova N., Zarembo K. (2017), Introduction to the Special Issue Civil Society in Ukraine: Building on Euromaidan Legacy, "Kyiv-Mohyla Law and Politics Journal" 3.

Christensen R. K., Rakhimkulov E. R., Wise C. R. (2005), The Ukrainian Orange Revolution brought more than a new president: What kind of democracy will the institutional changes bring?, "Communist and Post-Communist Studies", vol. 38.

Diuk N. (2014), Finding Ukraine, "Journal of Democracy", July, vol. 25, no. 3.

Diuk N. (2006), The Triumph of Civil Society, in: Revolution in Orange: the Origins of Ukraine's Democratic Breakthrough, eds. A. Aslund, M. McFaul, Carnegie Endowment for International Peace, Washington, DC.

Forbrig J., Demes P. (2007), Reclaiming Democracy. Civil Society and Electoral Change in Central and Eastern Europe, The German Marshall Fund, Washington.

Frye T. (1997), A politics of institutional choice in post-communist presidencies, "Comparative Political Studies", vol. 30, no. 5.

Gorbulin V., Vlasiuk O. (2015), Analityczna dopovid do shchrichnogo poslannia prezydenta Ukrainy do Verhovnoi Rady „Pro zovnishne i vnutrishne stanovyshche Ukrainy v 2015 roci", Kyiv.

Harnec O., Honcharuk O., Dmytruk N., Tkachuk A. (2013), Decentralization in Ukraine: Sociological Point of View, Kyiv.

Izha M., Krupnyk A. (2012), Transformacija publichnogo upravlinnia v umovach socialno-politychnoi modernizaciji Ukrainy, in: Aktualni problemy derzhavnogo upravlinnia, Odesa.

Karatnycky I., Ackerman P. (2005), How Freedom is Won. From Civic Resistance to Durable Democracy, Freedom House.

Kaskiv V., Chupryna I., Zolotariov Y. (2007), It's Time! Pora and the Orange Revolution in Ukraine, in: Reclaiming Democracy. Civil Society and Electoral Change in Central and Eastern Europe, eds. J. Forbrig, P. Demes, The German Marshall Fund, Washington.

Kosiewski P. (2003), Lata doświadczeń i perspektywa europejska, in: Polska-Ukraina, Wspótpraca organizacji pozarządowych, Fundacja im. Stefana Batorego, Warszawa.

Ksenicz I. (2018), Od reformy do reformy. Wspótpraca władz lokalnych i regionalnych Polski i Ukrainy w latach 1999-2014, Zalesie Górne.

Kuzio T. (2001), Identity and nation-building in Ukraine. Defining the 'Other', in: Ethnicities, Sage Publication, London.

Kolodiy A. (2002), Na shliahu do gromadianskogo suspilstva. Teoretychni zasady $i$ sociokulturni pereumovy demokratychnoi transformaciji v Ukraini, Lviv 
Chervona Kalyna, http://political-studies.com/wp-content/uploads/2010/01/ Kolodiy_Na_Slyahu.pdf, 2.10.2018.

Kovbasiuk Y. (2014), Misceve samovriaduvannia v Ukraini: suchasnyi stan ta osnovni napriamy modernizacii, Kyiv.

Levine P. (2013), We Are the Ones We Have Been Waiting For, Oxford University Press.

Levine P., Lee M. (2016), A new Model for Citizen Engagement, in: Stanford Social Innovation Review, https://ssir.org/articles/entry/a_new_model_for_citizen_ engagement.

Marchenko A. (2014), Comparisons of Civic Engagement in Europe: Evidence from European Values Study, "Slovak Journal of Political Science", vol. 14, no. 4.

Lutsevych O. (2013), How to Finish a Revolution: Civil Society and Democracy in Georgia, Moldova and Ukraine, Chatham House.

Schock K. (2015), Civil Resistance: Perspectives on Nonviolent Struggle, University of Minnesota Press.

Shapovalova N. (2019), Assessing Ukrainian Grassroots Activism Five Years After Euromaidan, https://tinyurl.com/y688rgkc, 2.10.2018.

Sirianni C. (2009), Investing in Democracy: Engaging Citizens in Collaborative Governance, Brookings Institution Press, Washington, D.C.

Skorupska A. (2015), The Role of Local Governments in National Foreign Policy in Poland, in: Strategic File, eds. M. Zaborowski, W. Lorenz, no. 7 (70), PISM.

Sołtan K. (2014), The Emerging Field of a New Civils, in: Civil Studies. Bringing Theory to Practice, eds. P. Levine, K. Sołtan, Washington.

Taczyńska J. (2013), Wspótpraca polskich jednostek samorzadu terytorialnego z władzami regionalnymi i lokalnymi oraz innymi podmiotami z państw objętych inicjatywa Partnerstwa Wschodniego, http://www.umww.pl/attachments/ article/36935/Partnerstwo $\% 20$ Wschodnie $\% 20 \%$ E2\%80\%93\%20Samorzady. pdf, 1.10.2018.

Vinnikov O. (2012), Pokaznyky rozvytku gromadianskogo suspilstva v Ukraini, Kyiv.

Umland A., Levitas A., Rabinovych M. (2018), From Amalgamation of Local Communities to a New Governance System in Post-Euromaidan Ukraine, 19.06.2018, http://neweasterneurope.eu/2018/06/19/amalgamation-local-communitiesnew-governance-system-post-euromaidan-ukraine/, 7.10.2018.

Way L. (2014), Civil Society and Democratization, Journal of Democracy, vol. 25, no. 3 .

Worschech S. (2017), New Civic Activism in Ukraine: Building Society from Scratch?, Civil Society in Ukraine: Building on Euromaidan Legacy, "Kyiv-Mohyla Law and Politics Journal" 3.

Zukin et al. (2006), A New Engagement? Political Participation, Civic Life, and the Changing American Citizen, Oxford University Press.

\section{Reports, Articles, Summaries}

2018 CIVICUS report, People Power Under Attack, https:/www.civicus.org/index. $\mathrm{php} /$ media-resources/reports-publications. 
Decentralization Offering Better Results and Efficiency (DOBRE), https://donors.decentralization.gov.ua/en/project/dobre.

Nations in Transit 2018. Ukraine, https://freedomhouse.org/report/nations-transit/ 2018/ukraine, 4.10.2018.

President: Decentralized political system will make us closer to Europe, 16.07.2015, https://www.president.gov.ua/en/news/decentralizaciya-nablizit-nashu-politichnu-sistemu-do-yevrop-35658, 7.10.2018.

Projekt zmin do Konstytuciji zberigaje balans vlady - Glava Venecianskoi komisii, 7.07.2015, “The Insider", http://www.theinsider.ua/politics/559bb0616c6fe/, 5.10 .2018 .

Political parties' programs: What to choose when there's nothing to choose from, 20.10.2014, "Vox Ukraine", http://voxukraine.org/2014/10/20/political-partiesprograms-what-to-choose-when-theres-nothing-to-choose-from/, 5.10.2018.

The 2016 CSO Sustainability Index for Central and Eastern Europe and Eurasia, https://www.usaid.gov/sites/default/files/documents/1866/CSOSI_Report_ 7-28-17.pdf, 4.10.2018.

The Foundation in Support of Local Democracy: http://www.frdl.lublin.pl/projekty/wrs. Ukraine 2020 Development Strategy, http://www.reforms.in.ua/Content/download/ Strategy2020updUA.pdf, 4.10.2018.

\section{Społeczeństwo obywatelskie jako aktor w procesach politycznych reformy samorządowej na Ukrainie}

\section{Streszczenie}

Jednym z pierwszych dokumentów przyjętych przez nowe władze na Ukrainie w następstwie Rewolucji Godności w 2014 r. była nowa koncepcja reformy samorządu i organizacji władzy terytorialnej na Ukrainie. Zarówno dany dokument, jak i oficjalne deklaracje czołowych polityków dotyczące konieczności wzmocnienia pozycji obywateli ukraińskich w procesie decyzyjnym i kształtowaniu ich lokalnych społeczności, doprowadziły do pozytywnych oczekiwań dotyczących transformacji samorządu na Ukrainie. W związku z powyższym, w artykule poruszono kwestię podstaw prawnych określających funkcjonowanie społeczeństwa obywatelskiego na Ukrainie z akcentem na głównych próbach przeprowadzenia reformy, a także na głównych rezultatach realizowanych działań. Ponadto nacisk kładzie się na obecny stan współpracy między aktorami społecznymi i politycznymi oraz na charakterystykę udziału społeczeństwa obywatelskiego w procesie decyzyjnym dotyczącym decentralizacji i reformy samorządu na Ukrainie.

Słowa kluczowe: społeczeństwo obywatelskie, Ukraina, reforma samorządu terytorialnego 